\title{
Is the rating of perceived exertion planned by the personal trainer similar to subject's perception? A pilot study
}

\section{A percepcão subjetiva de esforco planejada pelo treinador personalizado é similar à do aluno? Um estudo piloto}

Witalo Kassiano ${ }^{1,2}$

(D) https://orcid.org/0000-0002-0868-8634

Cláudio Assumpção²

(D) https://orcid.org/0000-0003-1226-5041

Ulisses Cunha ${ }^{2}$

(D) https://orcid.org/0000-0002-4640-6351

Karla de Jesus 3,4

(D) https://orcid.org/0000-0002-8918-8630

Mário Simim²

(D) https://orcid.org/0000-0002-4659-8357

Alexandre Medeiros²

(D) https://orcid.org/0000-0002-0447-353X

Abstract - The present study aimed to compare the intensity planned by the Personal Trainers (PTs) with that perceived by subjects in resistance training. Six male and female practicing resistance training ( 4 males and 2 females with mean age $33.0 \pm 6.16$ years, $1.3 \pm 0.55$ years training with follow-up) and two PTs participated in the study (average $32.0 \pm 4.0$ years, postgraduates, with a five -year or more experience). The comparison between the intensity planned by the PT and the intensity experienced by the subjects was determined by the Rating of Perceived Exertion (RPE). Previously, at the beginning of each training, the PT should respond individually to the RPE estimated for each student in that training session. At the end of each session, 30 minutes after its completion, this same scale was answered by the subjects. To compare the intensity of the sessions perceived by the subjects and that planned by the PTs, we used descriptive statistics, standardized mean differences and their confidence intervals. Results have showed that subjects reported substantially higher intensities (small effect size) when compared to PTs. It has been concluded that the intensity experienced by the subjects was substantially higher than that planned by the PTs.

Key words: Intensity; Monitoring; Resistance training; Supervision.

Resumo - Objetivou-se comparar a intensidade planejada pelos treinadores personalizados com a percebida por alunos no treinamento resistido. Participaram do estudo seis praticantes de treinamento resistido (4 homens e 2 mulheres; média de idade 33,0 $\pm 6,16$ anos, 1,3 $\pm 0,55$ anos treinando com acompanhamento) e dois treinadores personalizados (média de 32,0 \pm 4,0 anos, pós-graduados, com experiência acima de cinco anos atuando como treinador personalizado. A comparação entre a intensidade planejada pelo treinador personalizado e a intensidade experienciada pelos alunos foi realizada através da aplicação da escala de percepção subjetiva do esforço (PSE). Previamente, ao início de cada treino, o treinador personalizado respondeu individualmente a PSE estimada para cada aluno naquela sessão de treinamento, e ao final de cada sessão, 30 minutos após seu término, esta mesma escala era respondida pelos alunos. Para a comparação entre a intensidade das sessóes percebidas pelos alunos e a planejada pelos treinadores utilizamos as diferenças de médias estandardizadas, intervalos de confiança. Houve diferença substancial entre a PSE pretendida pelos treinadores personalizados e a experienciada pelos alunos no treinamento resistido. A intensidade percebida pelos praticantes foi maior do que a planejada pelos treinadores personalizados.

Palavras-chave: Intensidade; Monitoramento; Supervisão; Treinamento resistido.

1 Londrina State University. Physical Education and Sports Center. Londrina, PR. Brazil.

2 Federal University of Ceará. Institute of Physical Education and Sports. Biodynamics Research Group of Human Movement. Fortaleza, CE. Brazil.

3 Federal University of Amazon. Faculty of Physical Education and Physiotherapy. Human Performance Studies Laboratory. Manaus, AM. Brazil.

4 Federal University of Amazon. Faculty of Physical Education and Physiotherapy. Human Motor Behaviour Studies Laboratory. Manaus, AM. Brazil.

Received: 22 April 2019 Accepted: 07 January 2020

How to cite this article Kassiano W, Assumpção C, Cunha U, Jesus K, Simim M, Medeiros A. Is the rating of perceived exertion planned by the personal trainer similar to subject's perception? A pilot study. Rev Bras Cineantropom Desempenho Hum 2020, 22:e63257. DOI: http://dx.doi.org/10.1590/19800037.2020v22e63257

Copyright: This work is licensed under a Creative Commons Attribution 4.0 International License. 


\section{INTRODUCTION}

A "personal trainer" (PT) is a Physical Education expert, skilled to plan and execute individual training aiming health ${ }^{1,2}$ and wellbeing ${ }^{3}$. Literature in this scope has already demonstrated that training programs monitored by specialists present greater improvements and so their practitioners in comparison to unsupervised interventions ${ }^{4-6}$. Therefore, an increasing population's concerning is growing, having in consideration aspects related to health and quality of life ${ }^{1}$. This setting has been favouring an increasing in the search for a personal trainer's supervision and monitoring in physical activity practice ${ }^{1,4}$.

To promote the improvement of physical fitness it is necessary a training plan and its systematization, watching the external load, the stimuli offered to the subject (i.e. weekly attendance, number of exercises, overload) and the internal effects (i.e. heart rate, delayed-onset muscle soreness, perceived effort) resulting from training ${ }^{7,8}$. PT's knowledge in using tools allowing the follow-up of changes resulting from the intervention program, might potentiate subjects' positive adaptations, mainly to provide better adjustments in the training loads and suitable recovery periods $s^{9,10}$.

Currently, there are several tools to monitor the chronic and acute effects of training internal load ${ }^{11,12}$ and among them is the Borg Rating of Perceived Exertion Scale (RPE Scale) ${ }^{13}$, adapted by Foster et al. ${ }^{14}$. This is a 0-10 item scale tool and hypothesizes that the physiological responses of physical stress are followed by average perceived answers ${ }^{14}$. Results found using RPE scale have been effective in positive adaptations, both in high performance $\mathrm{e}^{15-17}$ and in the health scope $\mathrm{e}^{9,18,19}$. RPE scale is also a simple and low-cost strategy to training load monitoring and control ${ }^{20}$. In this sense, to meet the pre-established goals it is necessary a balanced relationship between the training load planned by the PTs ,i.e. RPE score, and that perceived by the subjects ${ }^{14,21}$.

However, for example, in the Sciences of Sport have been reporting a gap between what has been planned by the coach and that perceived by the athletes ${ }^{15-17,21}$. Brink, Frencken ${ }^{21}$ have demonstrated that juvenile football players have perceived the training more intensely than what has been planned by the coach ${ }^{21}$, which can favour overtraining ${ }^{17}$. Foster, Heimann ${ }^{14}$ suggest that one of the potential causes in the triggering of negative results in training is the incompatibility between the external load planned by the coach and the internal load perceived by the athletes.

Row, Knutzen ${ }^{18}$ have reported in relation to health, the effectiveness when prescribing loads in resistance training, according to RPE reported by the subject. However, to the best of our knowledge, to date, no study has compared the intensity planned by the $\mathrm{PT}$ or fitness professional and that experienced by the subject in the resistance training. These findings can contribute to the control and improvement of the relationship dose/response in the resistance training under supervision and individual prescription. Hence, the objective of the current research was to compare the intensity planned by PTs to that perceived by the subjects in the resistance training. 


\section{METHOD}

\section{Subjects}

Six subjects practicing resistance training participated in the study, both genders, four men and two women aged $33.0 \pm 6.1$ years; $1.3 \pm 0.5$ years with follow-up training and two PTs $32.0 \pm 4.0$ years old, experienced over five years as personal trainer. Inclusion criterion: subjects should attend training at least, three times a week, practicing time equal or above six months and with no injury report. PTs should be graduated in Physical Education, Post-graduation lato sensu, and holding, at least, a three- year experience in personal training. All the volunteers have been informed about study procedures. Data collection occurred as a training routine and the PTs were familiarized in recording the session intensity perceived by the subjects ${ }^{22}$. The protocol was written in accordance with the standards established by the Declaration of Helsinki.

\section{Procedures}

Data collection has been carried out during volunteers' training sessions, totalling 20 sessions for six weeks. Sessions performed in the two first weeks (6 sessions) underpinned RPE. To guarantee a better subjects and PTs' RPE response reliability, the underpinning procedures have been used as described by Robertson, Goss ${ }^{23}$. Training has been carried out meeting each subject's specific goals, without interference from the study researchers. Box 1 presents subjects' general planned training characteristics. All the sessions have been performed by the subjects in the habitual gym, maintaining their routine procedures. Previously, at the beginning of each training, the PT responded individually each subject's planned RPE and at the end of each session, after 30 minutes, this scale was responded by the subjects ${ }^{12}$.

Box 1. General characteristics of training planned by PTs.

\begin{tabular}{|l|l|l|l|}
\hline Training A & \multicolumn{2}{l}{ Training B } & \multicolumn{2}{l|}{ Training C } \\
\hline $\begin{array}{l}\text { Warm-up and joint mobility } \\
\text { exercises }\end{array}$ & $\begin{array}{l}\text { Warm-up and joint mobility } \\
\text { exercises }\end{array}$ & $\begin{array}{l}\text { Warm-up and joint mobility } \\
\text { exercises }\end{array}$ & $\begin{array}{l}\text { Warm-up and joint mobility } \\
\text { exercises }\end{array}$ \\
\hline $\begin{array}{l}\text { Major Training: } \\
\text { Back, Biceps and forearms. }\end{array}$ & $\begin{array}{l}\text { Major Training: Chest, shoul- } \\
\text { ders and triceps. }\end{array}$ & $\begin{array}{l}\text { Major training: } \\
\text { Hip, calf and abdominals. }\end{array}$ & $\begin{array}{l}\text { Major Training: Shoulders, } \\
\text { Trapezius and forearms. }\end{array}$ \\
\hline 3 sets of 8 to 12 repetitions & 3 sets of 8 to 12 repetitions & 3 sets of 8 to 12 repetitions & 3 sets of 8 to 12 repetitions \\
\hline $\begin{array}{l}\text { - Stretching and Myofascial } \\
\text { Release. }\end{array}$ & $\begin{array}{l}\text { - Stretching and Myofascial } \\
\text { Release. }\end{array}$ & $\begin{array}{l}\text { - Stretching and Myofascial } \\
\text { Release. }\end{array}$ & $\begin{array}{l}\text { - Stretching and Myofascial } \\
\text { Release. }\end{array}$ \\
\hline
\end{tabular}

\section{Statistical Analysis}

Initially, mean and standard deviations have been calculated using descriptive statistics. Later, the comparison between the intensity perceived by the subjects and that planned by the PTs was analysed through the magnitude-based inference ${ }^{24}$, standardized mean differences (SMD) and their confidence intervals (CI=90\%). The quantitative probability of finding differences between PTs' and subjects' RPE has been qualitatively assessed through the scale: < 1\%, almost certainly not; $1-5 \%$, very unlikely; 
5-25\%, unlikely; 25-75\%, possible; 75-95\%, likely; 95-99\%, very likely; $>99 \%$, almost certain.

\section{RESULTS}

Figure 1 presents subjects' intensity scores and those planned by the PTs, during training sessions. All the sessions have been rated as high intensity $(\mathrm{RPE}>5)$.

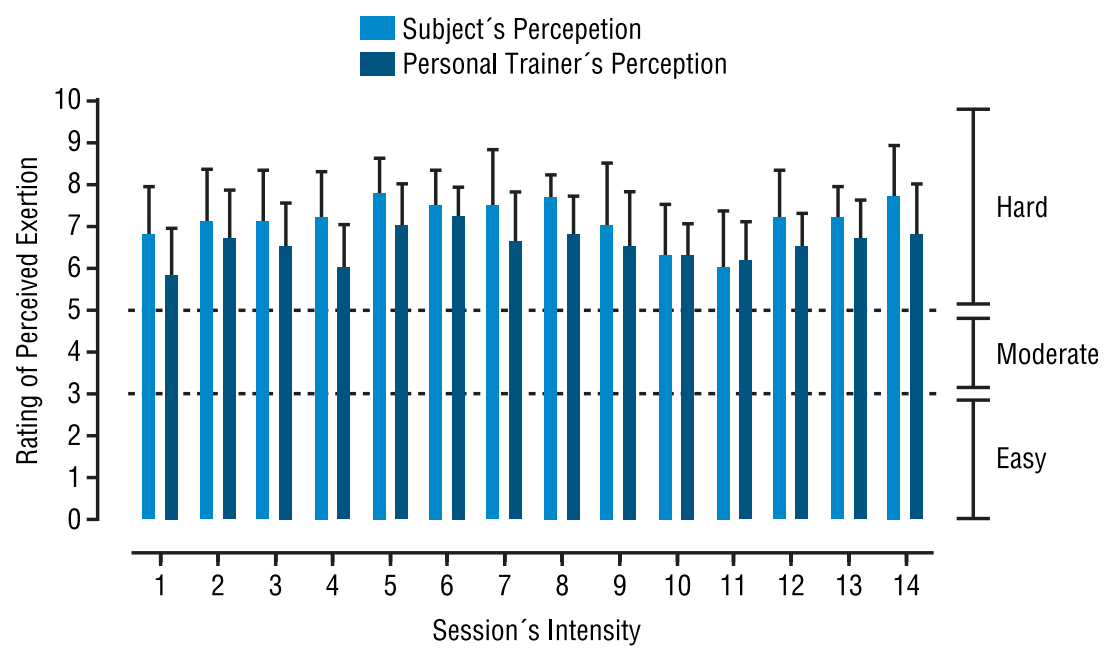

Figure 1. Description of intensities (mean and standard deviation) experienced by the subjects and planned by PTs throughout training sessions.

Figure 2 presents the comparison between subject's perception of intensity and that planned by the PT. Subjects reported intensities substantially higher (effect size) when compared to PTs'.

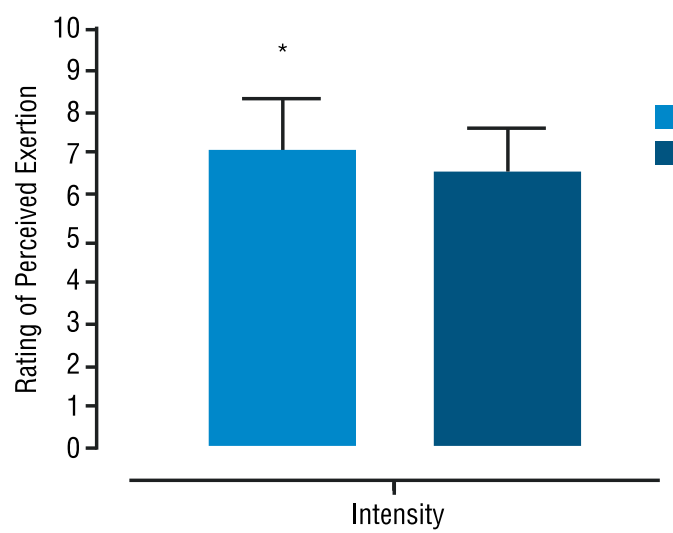

Subject's Percepetion

Personal Trainer's Perception

$\operatorname{SMD}(90 \% \mathrm{Cl})=-0,45(-0,69 ;-0,21)$

Effect size $=$ small

Probability $=0 / 4 / 96$ ( ${ }^{*}$ very likely)

Figure 2. Comparison between subjects' perception of intensity and that planned by PTs.

\section{DISCUSSION}

This study aimed to compare the intensity planned by the PT and the one perceived by the subjects in the resistance training. To the best of our knowledge, this has been the first investigation to compare the intensity perceived by the recreational practitioner and the one planned by the PT. 
The main finding was that the RPE score experienced by the subjects was higher than the one planned by the PTs, being both RPE (planned and perceived) rated as "high intensity" $(\mathrm{RPE}>5)^{25}$.

In the training setting, strong disagreements between coaches' planned contents and athletes' perception have been highlighted as a risk factor that might trigger the decreasing of sportive adaptation ${ }^{14,17}$, e.g. when planning a light stimulus session and the athletes' perception is not in the same line of agreement with the planned intensity. This scenario might provide the responses of an over or under estimated training, mainly due to an unsuitable recovery $y^{14,17}$ or in the absence of no physical fitness improvement ${ }^{14,17}$.

Although substantial differences have been found in RPE score, the impact of this difference has been small (ES = Small). If we take in consideration Foster, Florhaug ${ }^{25}$ proposal, it is possible to acknowledge that there has been a high agreement in the planned and perceived intensity zone . This enables us to infer that the coach was aware of the session impact, and thus, in the know to allow him to adjust the interval between strong stimuli.

Our findings corroborate the literature. Recent investigations conducted in team sports have been finding low connection between coaches' planning and athletes' perception ${ }^{15,17}$. On the other hand, individual sports have shown dissimilar findings. Some researches evidence a nearness between coach and athlete's $\mathrm{RPE}^{14,16}$ others report disagreement ${ }^{26}$. The latter scenario theoretically favours a greater closeness between what has been planned by the PT/coach and the subjects/athletes' perception, hence allowing a personalized adjustment and a greater external training load control (i.e. repetition number, under pressure time, overload). However, even regulating the external load (i.e. volume, intensity, frequency) of two subjects, they might distinctively perceive the effort due to some factors, such as, readiness, training and injury background ${ }^{20}$.

Scantlebury, Till ${ }^{17}$ in a study comprising several modalities (rugby, hockey, football) reported that the connection between the planned and the perceived RPE tends to increase all the season through, as well as the agreement between RPE and the intensity [\% Repetition Maximum (RM)], which also increases according to the subject/athlete's training level ${ }^{27}$. These findings suggest that it might exist a minimum period where the PTs could be more sensitive in predicting sessions intensity, and that in the resistance training sessions the overload control (\%RM) is reliable to better predict practitioner's RPE.

Despite having the above mentioned data, the majority of the researches has been conducted in the sportive performance scope $\mathrm{e}^{15-17}$, which precludes greater conclusions on recreational practitioners of resistance training. The current investigation has shown that $100 \%$ of the sessions has been rated as "intense" (i.e. PSE $>5$ ) 25 , suggesting a high index of monotony, which is in the Sport Sciences an adverse characteristic to improve performance ${ }^{25}$. Nevertheless, our data is not conclusive of resistance training in recreational practitioners, in relation to training load monotony, taking into consideration the small number and the interval between sessions. 
The high session intensity found in the current study has shown that strength drills for lower limbs have evidenced higher RPE scores than the drills for upper limbs ${ }^{28}$. Among the four weekly sessions performed by the participants, only one has been specifically directed to these muscle sets. Other factors can trigger a greater RPE, such as, the session total volume $^{28}$, drill overload (\%RM), practitioner's previous experience and recovery level ${ }^{20}$. PT's knowledge on these factors might contribute to a greater agreement between what has been planned and what has been experienced by the subject.

Planning intense sessions can be justified by the additional gains that stronger stimuli promote on physical fitness and body composition ${ }^{29}$. Another factor influencing Pts' to apply heavy stimuli is the small quantity of weekly sessions (i.e. three sessions), hindering two intense stimuli on the same muscle $\operatorname{set}^{30}$.

This investigation holds some limitations, such as, the non-monitoring of some variables of external load, i.e., drills overload and session total volume, which, as shown above, have influence on RPE. Further studies should verify these variables and help to respond to literature gaps on the relationship between what is planned by PTs and what is perceived by their subjects. Also, studies ought to follow this population's mediumand long-term adaptations, concerning the agreement or disagreement between what has been planned by the PT and what has been perceived by the resistance training subject.

\section{CONCLUSION}

Current results have demonstrated that RPE scores reported by the subjects have been substantially higher (effect size) than those planned by PTs. However, both have presented a proneness to high intensity zone.

\section{Acknowledgments}

The authors thank all the subjects for their engagement in this study.

\section{COMPLIANCE WITH ETHICAL STANDARDS}

\section{Ethical aspects}

The protocol was written in accordance with the standards established by the Declaration of Helsinki. All the volunteers have been informed about study procedures. Data collection occurred as a training routine and the PTs were familiarized in recording the session intensity perceived by the subjects.

\section{Conflict of interest statement}

The authors declare that they have no competing interests.

\section{Author Contributions}

Conception and design of the experiment: AIAM, UC and WK. Reali- 
zation of the experiments: UC. Data analysis: WK, AIAM, CA, KJ and MS. Article Writing: WK, KJ and MS. All authors read and approved the final version of the manuscript.

\section{REFERENCES}

1. Bossle CB. The personal trainer and the care of self: a perspective of professional mediation. Mov 2008; 14: 187-1998.

2. Kravitz L. Highly effective personal training: an evidence-based review of teaching strategies. Strength Cond J 2010; 32: 87-89.

3. Anversa ALB, Oliveira AAB. Personal trainer: professional skills required by the job market. Pensar Prát 2011; 14.

4. Mazzetti SA, Kraemer WJ, Volek JS, Duncan ND, Ratamess NA, Gómez AL, et al. The influence of direct supervision of resistance training on strength performance. Med Sci Sports Exerc 2000; 32: 1175-1184.

5. Lacroix A, Hortobágyi T, Beurskens R, Granacher U. Effects of supervised vs. unsupervised training programs on balance and muscle strength in older adults: a systematic review and meta-analysis. Sports Med 2017; 47: 2341-2361.

6. Coutts AJ, Murphy AJ, Dascombe BJ. Effect of direct supervision of a strength coach on measures of muscular strength and power in young rugby league players. J Strength Cond Res 2004;18(2):316-23.

7. Bartlett JD, O'Connor F, Pitchford N, Torres-Ronda L, Robertson SJ. Relationships between internal and external training load in team-sport athletes: evidence for an individualized approach. Int J Sports Physiol Perform 2017; 12: 230-234.

8. Cardinale M, Varley MC. Wearable training-monitoring technology: applications, challenges, and opportunities. Int J Sports Physiol Perform 2017; 12: S255-S262.

9. Helms ER, Byrnes RK, Cooke DM, Haischer MH, Carzoli JP, Johnson TK, et al. RPE vs. percentage $1 \mathrm{RM}$ loading in periodized programs matched for sets and repetitions. Frontiers in Physiol 2018; 9: 247.

10. Shinya Yamauchi SM. Rating of perceived exertion for quantification of the intensity of resistance exercise. Int J Phys Med Rehabil 2013; 01.

11. Borresen J, La mbert MI. The quantification of training load, the training response and the effect on performance. Sports Med 2009; 39: 779-795.

12. Nakamura FY, Moreira A, Aoki MS. Monitoramento da carga de treinamento: a percepção subjetiva de esforço da sessão é um método confiável? J Phys Educ 2010; 21: 1-11.

13. Borg GA. Psychophysical bases of perceived exertion. Med Sci Sports Exerc 1982; 14: 377-381.

14. Foster C, Heimann KM, Esten PL, Brice G, Porcari JP. Differences in perceptions of training by coaches and athletes. S Afr J Med Sci 2001; 8: 3-7.

15. Andrade FC, Nogueira RA, Coimbra DR, Miloski B, Freitas VH, Filho MB. Internal training load monitoring across a period training in volleyball players. Rev Bras Cineantropom Desempenho Hum 2014; 16(6):638.

16. Wallace LK, Slattery KM, Coutts AJ. The ecological validity and application of the session-RPE method for quantifying training loads in swimming. J Strength Cond Res 2009;23(1):33-8.

17. Scantlebury S, Till K, Sawczuk T, Weakley J, Jones B. Understanding the relationship between coach and athlete perceptions of training intensity in youth sport. J Strength Cond Res 2018;32(11):3239-3245.

18. Row BS, Knutzen KM, Skogsberg NJ. Regulating explosive resistance training intensity using the rating of perceived exertion. J Strength Cond Res 2012;26(3):664-71.

19. Lazzirini BS, Dropp MW, Lloyd W. Upper-extremity explosive resistance training with older adults can be regulated using the rating of perceived exertion. J Strength Cond Res 2017;31(3):831-836. 
20. Abbiss CR, Peiffer JJ, Meeusen R, Skorski S. Role of ratings of perceived exertion during self-paced exercise: what are we actually measuring? Sports Med 2015; 45: 1235-1243.

21. Brink MS, Frencken WG, Jordet G, Lemmink KA. Coaches' and players' perceptions of training dose: not a perfect match. Int J Sports Physiol Perform 2014; 9: 497-502.

22. Winter EM, Maughan RJ. Requirements for ethics approvals. J Sports Sci 2009; 27: 985.

23. Robertson RJ, Goss FL, Rutkowski J, Lenz B, Dixon C, Timmer J, et al. Concurrent validation of the OMNI perceived exertion scale for resistance exercise. Med Sci Sports Exerc 2003; 35: 333-341.

24. Hopkins W. Linear models and effect magnitudes for research, clinical and practical applications. Sportscience 2010; 14: 49-58.

25. Foster C, Florhaug JA, Gottschall L, Hrovatin LA, Parker S, Doleshal P, et al. A new approach to monitoring exercise training. J Strength Cond Res 2001; 15 : 109-115.

26. Cruz R, Fretas JV, Santos JPNR, Castro PHC, Siqueira R, Alves DL, et al. Comparison between the RPE planned by coach with perceived by youth athletes of track and field. Rev Bras Ciên Mov 2017; 25: 13-18.

27. Testa M, Noakes TD, Desqorces FD. Training state improves the relationship between rating of perceived exertion and relative exercise volume during resistance exercises. J Strength Cond Res 2012; 26: 2990-2996.

28. Lodo L, Moreira A, Zavanela PM, Newton MJ, McGuigan MR, Aoki M. Is there a relationship between the total volume of load lifted in bench press exercise and the rating of perceived exertion? J Sports Med Phys Fit 2012; 52: 483-488.

29. Mayer F, Scharhag-Rosenberger F, Carlsohn A, Cassel M, Muller S, Scharhag $\mathrm{J}$. The intensity and effects of strength training in the elderly. Dtsch Arztebl Int 2011; 108: 359-364.

30. Ralston GW, Kilgore L, Wyatt FB, Baker JS. The effect of weekly set volume on strength gain: a meta-analysis. Sports Med 2017; 47: 2585-2601.

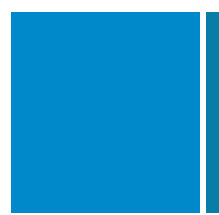

\section{Corresponding author}

Alexandre Igor Araripe Medeiros, PhD

Av. Mister Hull, Parque Esportivo - Bloco 320, Campus do Pici

CEP 60455-760 -Fortaleza - CE. Brazil.

Institute of Physical Education and Sports

Email: alexandremedeiros@ufc.br 